\title{
Family's Addressing Male and Female Batak Toba Tribe in Indonesia
}

\begin{abstract}
| Bambang Nur Alamsyah Lubis ${ }^{1}$ | Asnawi ${ }^{2}$ |
${ }^{1}$ Faculty of Teaching Training and Education, Universitas Prima Indonesia, Medan, Indonesia

${ }^{2}$ Faculty of Teaching Training and Education, Universitas Muslim Nusantara AlWashliyah, Medan, Indonesia

${ }^{1}$ bambangnuralamsyahlubis @unprimdn.ac.id

2awi.umn2005@qmail.com

\author{
ABSTRACT \\ This study deals with family addressing male and female in Batak \\ Toba Language. The aim of this study to analyse the addresse of \\ Batak Toba people in their social life. This study used descriptive \\ qualitative as a method of reserach. This study was analyse the \\ result of interview of Batak Toba people. The result, there were \\ tweenty male and female addresses that was used by Batak Toba \\ people in family interaction. This adresse is used to show the level \\ of satus and to show respect to the oldest and love to the \\ youngest family member. \\ KEYWORDS \\ addresse; Batak Toba tribe; male and female; family; culture.
}

\section{INTRODUCTION}

An identity of a society is shown by its language, because a language tells the cultural background of society itself. Language makes human life more interesting. Because of language, there are many interactions between one human to another, one group of societies to another group society. Language is one of important thing in human life, because language is basic things to connect one people to other. Many languages in this world, every specific place has specific language that is used by group of human that stay in one of world's part. Language also builds one culture in a specific area. Because language teaches one of group society understand to interact with their own group that can be a way to support development of their culture. In the real fact, many ethnics languages almost endangered in many areas when they communicate each other in their community (Akmal, et al, 2021). If a language had specific words to explain something or create differences, while another language did not have similar words, then first language speakers will find easier to talk about those things and understand about their environment differences. These effects imply that the language of a person uses places limits both on what is possible to say and perhaps, more importantly, on what is possible to think. Language is constantly being built into practice. Both language and gender are basically inveterate in social practice, and acquiring their meaning from the human activities in which they exist. Male and female are socially different because society sets different social rules for them and expects different patterns of behavior. Thus, gender refers not only to sexual differences but also to a set of socially defined roles, and identities that people develop in socialization processes involving power relations. Gender is referred to specific language. In life communication, addressing specific one is an important point to social relationship. Addressing had specific social functions: recognition of social identity, social position, the role of the recipient and the reciprocal relationship between the speaker and the recipient. It can build, maintain and strengthen all kinds of interpersonal relationships. Generally speaking, addressee terms divide into four categories: kinship terms, social titles (genetic titles, official titles and occupational titles), names and indicating pronouns. In this article, mainly discuss the terms of kinship, genetic and official title. The choice of addressee is regulated by various social factors: particular opportunity, 
social status or rank, gender, age, family relationship, hierarchy, race or transactional status. When family ties are overpowering, the term of kinship will play a very important role inside family and society. When racial or social rank is crucial in society, an addressee terms that show respect and hierarchy are preferred; whereas in a society that claims to be egalitarian, the term of addressee may not be that important. Therefore, there were a very close relationship between addressee terms and culture. In this paper, the researcher explores Batak Toba addressee in society based on the culture, because Batak Toba has specific addressee when call someone older, younger or the same age. Not only that they need to know also when their addressee is male or female, becasue the addressee shows the politeness of someone in communication.

Indonesia, and it is often called as "Batak Klasik". Batak Toba tribes is found in Kabupaten Toba Samosir,m Kabupaten Humbang Hasundudtan, Kabupaten Samosir and Kabupaten Tapanuli Utara, some of them are spread in Kabupaten Dairi, Kabupaten Tapanuli Tengah, Sibolga and some others area in North Sumatere. Batak Toba people speak in Batak Toba language and centrally in Lake Toba and Samosir Island in the middle of lake. Batak Toba people frequently construct a building with traditional architecture general Batak Toba in Samosir. Cultural demonstration, such as performance and celebration of Sigale-gale Statue frequently held for tourist. When the Batak kingdom was located in Bakara, the Sisingamangaraja dynasty of the Batak kingdom divided its kingdom into four regions under the name of King Maropat, namely:

a. Raja Maropat Silindung

b. Raja Maropat Humbang

c. Raja Maropat Toba

d. Raja Maropat Samosir

Batak Toba is one of Austronesian language umbrella, it spoken in the province of North Sumatra in Indonesia. It is part one of language group called "Bahasa batak". There are about 2,000,000 Batak Toba speakers. They lived in some part of Lake toba, such as the east, west and south of Lake Toba. It was historically written using the Batak script, but the Latin script is now used for most of the writing.

The name of this language appears based on the rich and complex history of ethnic identity in colonial and post-colonial Indonesia. This is the common name for the common language spoken by the people of the districts of Toba, Uluan, Humbang, Habinsaran, Samosir, and Silindung, which are centered on the island of Sumatra, more specifically, on Lake Toba. Linguistically and culturally these tribes are very closely related. Other nearby communities such as Silalahi and Tongging can also be classified as speakers of the Toba Toba Batak language.

Among the regencies mentioned above, Toba is the most densely populated and politically the most prominent, so "Batak Toba" has become a label for all people who speak a similar dialect to the dialect spoken in Toba. Present time, Indonesians are rarely referred to as "Batak Toba", but more commonly and simply as "Batak". Batak Toba people call it in their own language as "Hata Batak". This "Batak" language is different from the language of other "Batak" people who can be divided into speaking northern Batak dialects (Karo Batak, and Pakpak-Dairi Batak - linguistically this dialect group also includes the very culturally different Alas people), the middle Batak dialect (Simalungun) and other closely related southern Batak dialects such as Angkola and Mandailing.

\section{RESEARCH METHODS}

This study used descriptive qualitative method. The researcher is the key instrument, the other instrument that was used are sound and video recorder, they were used to record the 
interview Batak Toba people about the addresse. The data was result of interview and observation in Batak Toba environment to find out the accurate data.

\section{RESULTS AND DISCUSSION}

The researcher collects the data by interviewing some Batak Toba people and colleagues. The data name's adressing of gender are divided into male and female. There are twenty kinds of family's adresing in Batak Toba tribe in indonesia. Those adressings are used to daily life communication among family and society. they also are used to show respect and love to oldest ans youngest person in family member. Tabel below shows family's addressing male and female Batak Toba Tribe in Indonesia.

Tabel 1. Family's adressing

\begin{tabular}{|l|l|l|l|}
\hline No & $\begin{array}{l}\text { Addressing in } \\
\text { Bahasa Indonesia }\end{array}$ & $\begin{array}{l}\text { Addressing in } \\
\text { Batak Toba Tribe }\end{array}$ & $\begin{array}{l}\text { Addressing in } \\
\text { English }\end{array}$ \\
\hline 1 & Kakek & Opung doli & Grand father \\
\hline 2 & Nenek & Opung boru & Grand mother \\
\hline 3 & Ayah & Amang & Father \\
\hline 4 & Ibu & Inang & Mother \\
\hline 5 & Anak laki-laki & Anak & Son \\
\hline 6 & Anak perempuan & Boru & Daughter \\
\hline 7 & Sodara kandung laki-laki & Ito & Brother \\
\hline 8 & Sodara kandung perempuan & Ito & Sister \\
\hline 9 & Suami sodara kandung perempuan & Lae & Brother in law \\
\hline 10 & Istri sodara kandung laki-laki & Eda & Sister in law \\
\hline 11 & Menantu laki-laki & Hela & Son in law \\
\hline 12 & Menantu perempuan & Parumaen & Daughter in law \\
\hline 13 & Adik ayah laki-laki & Uda & Uncle \\
\hline 14 & Adik ayah perempuan & Namboru & Aunt \\
\hline 15 & Adik ibu laki-laki & Tulang & Uncle \\
\hline 16 & Adik ibu perempuan & Inang uda & Aunt \\
\hline 17 & Istri adik ayah laki-laki & Inang uda & Aunt \\
\hline 18 & Suami adik ayah perempuan & Amang boru & Uncle \\
\hline 19 & Istri adik ibu laki-laki & Tulang & Aunt \\
\hline 20 & Suami adik ibu perempuan & Uda & Uncle \\
\hline
\end{tabular}

Here, some of utterance in Batak Toba language in conversation. Example:

"Sian dia ho oppung?" (where do you want to go grandmother?)

"Di dia hela mu?" (where is your son in law?

"Nga mangan ho tulang?" (had you gotten your lunch, uncle?)

"On do nantulang $i$ ?" (is this your wife, uncle?)

"On ma anakku" (inilah anak laki-laki ku)

"On ma borukku" (inilah anak perempuan ku"

Based on the research findng, Batak Toba has specific addressee in communication especially inside of family member. Each addresse has specific person as a purpose of communication. Batak Toba cannot use random addresse to someone who is family member, when Batak Toba people try to start a conversation, they should know exactly who is person that receive a message, it means to know what exactly family's addresse that is going to use to greet specific person. If anyone who is wrog in using family's addressing, they are going to call as uncivilized, in Batak Toba language " dang maradat". 
That is way, Batak Toba must understand about family's addressing, it is used to make sure easy to communication among family members.

\section{CONCLUSION}

This paper shows how Batak Toba people addressee their family member. In Batak Toba there are twenty dominant addressees that rise up in family and the society. Batak Toba people create addressee to show their politeness in communication with family or society. It means the culture of Batak Toba teach us actually how to respect each other, such as the young to old one, the same age and the old to young one. Society is the largest part of human group member, inside of it there are any specific's cultures that keep it untill dying day. Especially in Batak Toba people. They use specific addressee to keep their cultural background. Wherever people hear specific addressee each other of people, they are going to know the speaker and addressee is Batak Toba people. Bata Toba people make it, because they keep respect to each other, to keep their culture and politeness in communication. That is way, addressee in Batak Toba always become something unique and interesting to be discussed. Every level in family, they have addressee. Male and female in family or society have their own addressee, and it is depend who is the speaker and to whom it is addressed.

\section{REFERENCES}

Akmal, \& Mulyadi. (2021). Relative Clauses in Minangkabau, Indonesian, English Languages (Typology Study). Randwick International of Education and Linguistics Science Journal, 2(2), 189-197. https://doi.org/10.47175/rielsj.v2i2.235

Attenborough, Frederick. (2014). "Words, contexts, politics". Gender and Language, special issue: Gender, language and the media. Equinox.

Aubrey, Jennifer Stevens; Harrison, Kristen (2004). "The gender-role content of children's favorite television programs and its links to their gender-related perceptions". Media Psychology. Taylor and Francis.

Barnes, Douglas. (1971). "Language and learning in the classroom". Journal of Curriculum Studies. Taylor and Francis.

Bucholtz, Mary. (2004). "Editor's introduction". In Lakoff, Robin (author); Bucholtz, Mary (editor). Language and woman's place: text and commentaries. New York: Oxford University Press.

Carli, Linda L. (1990). "Gender, language, and influence". Journal of Personality and Social Psychology. APA via PsycNET.

Fishman, Pamela (1977). "Interaction: The work women do". Social Problems. Oxford University Press.

Ginting, R. I., Lubis, B. N. A., \& Sinaga, D. A. (2021). The Revitalization of Tugu Silalahi Batak Toba Folklore into Teaching Materials in English Subject for Junior High School. Linguistic, English Education and Art (LEEA) Journal, 4(2), 240-248.

Ginting, S. D. B., Lubis, B. N. A., \& Sari, N. P. REVITALISASI LEGENDA SUKU KARO "PANCUR KUTA" SEBAGAI BAHAN AJAR KESUSASTERAAN DI PRODI PENDIDIKAN BAHASA DAN SASTRA INDONESIA UNIVERSITAS PRIMA INDONESIA. Kode: Jurnal Bahasa, 8(3).

Hall, Kira; Bucholtz, Mary, eds. (1995). Gender articulated: language and the socially constructed self. New York: Routledge.

Hammarström, Harald; Forkel, Robert; Haspelmath, Martin; Bank, Sebastian, eds. (2016). "Batak Toba". Glottolog 2.7. Jena: Max Planck Institute for the Science of Human History. 
Holmes, Janet; Meyerhoff, Miriam, eds. (2003). The handbook of language and gender. Malden, Massachusetts: Blackwell Pub.

Jesperson, O. (1922) Language: It's Nature, Development and Origin Allen \& Unwin, New York.

Lakoff, Robin (2004). Language and woman's place: text and commentaries. New York: Oxford University Press.

Lubis, B. N. A., Afrilyani, T. P., Girsang, S. W., Sihite, B. M. T., Chandra, S., \& Permadi, A. (2019). An Error Analysis On Changing Active Voice Into Passive Voice At Ninth Grade Of Smp Amir Hamzah Medan. EduTech: Jurnal Ilmu Pendidikan dan Ilmu Sosial, 5(2).

Lubis, B. N. A., \& Ginting, S. D. B. (2019). ASPEK GAYA WACANA ANTOLOGI CERPEN SAMPAN ZULAIHA KARYA HASAN AL-BANNA. Jurnal BahteraJurnal Pendidikan Bahasa Sastra dan Budaya, 6(12).

Lubis, B. N. A., Gurning, B., \& Saragih, A. (2019). Verbal semiotics resources employed in advertising cigarette on TV in Indonesia. Journal of Languages and Culture, 10(1), 1- 4.

Lubis, B. N. A., \& Sagala, R. W. (2020). The Comparative of Indonesian and Western Culture in Live Action: A Study of Cross-Culture. English Teaching and Linguistics Journal, 1(2), 56-59.

Nur, S. D. B. G. B., \& Lubis, A. "MAHANGKE" FOKLORE OF KARONESE ETHNIC AS A LITERATURE'S OBJECT LEARNING. In SUSUNAN KEPANITIAAN SEMINAR NASIONAL 23 NOPEMBER 2018 FKIP UNIVERSITAS PRIMA INDONESIA (p. 82).

Ritonga, M. G. S., Lubis, B. N. A., Simamora, W. R., \& Situmorang, R. (2021). The Revitalization of Patung Sigale-Gale Batak Toba Folklore into Teaching Material in English Subject for Junior High School. English Teaching and Linguistics Journal, 2(1), 89-97.

Sihombing, D. L., Lubis, B. N. A., Simbolon, A., \& Simamora, F. P. (2021). The Revitalization of "Aek Sipitu Dai" Batak Toba Folklore into Teaching Materials in English Subject for Junior High School. English Teaching and Linguistics Journal, 2(1), 112-121.

Sinamo, F. L., Lubis, B. N. A., Barus, T. A. E., \& Sembiring, S. J. (2021). The Revitalization of Batu Parsidangan Batak Toba Folklore Into Teaching Materials in English Subject for Junior High School. Linguistic, English Education and Art (LEEA) Journal, 4(2), 233-239.

Speer, Susan (2005). "Introduction: feminism, discourse and conversation analysis". In Speer, Susan A. Gender talk: feminism, discourse and conversation analysis. London New York: Routledge.

Tannen, Deborah. (2006). "Language and culture". In Fasold, Ralph W.; Connor-Linton, Jeff. An introduction to language and linguistics. Cambridge, UK New York: Cambridge University Press.

Tannen, Deborah. (1996). Gender and discourse. New York: Oxford University Press.

Wolfram, Walt; Schilling-Estes, Natalie, eds. (2006). American English: dialects and variation (2nd ed.). Malden, Massachusetts: Blackwell

Zimmerman, Don H.; West, Candace (1975). "Sex roles, interruptions and silences in conversation". In Thorne, Barrie; West, Candace. Language and sex: difference and dominance. Rowley, Massa chusetts: Newbury House Publishers. 